\section{Relations between the material structures and drying properties of ceramic bricks and roof tiles}

LÁszló A. Gömze - Department of Ceramics and Silicate Engineering, University of Miskolc • femgomze@uni-miskolc.hu

LudMILA N. GömZE - IGREX Engineering Service Ltd. • igrexkft@t-email.hu

Összefüggések tégla és cserépipari termékek anyagszerkezeti és száradási tulajdonságai között

(A XXIII. Téglás Napokon elhangzott elôadás alapján.)

Napjainkban, amikor az energiaköltségek eldönthetik egy-egy vállalat, vagy iparág versenyképességét, különösen fontos, hogy megértsük a tégla és cserépipari termékek szárításakor lejátszódó termodinamikai folyamatokat és anyagszerkezeti változásokat. Munkájukban a szerzốk rámutatnak a formázott nyers téglák és kerámia tetốcserepek anyag- és pórusszerkezetének a szárítási folyamatban betöltött szerepére, különös tekintettel a $100^{\circ} \mathrm{C}$-nál magasabb hômérsékleten történô szárítás lehetôségeire és korlátaira. Az elvégzett vizsgálatok, elemzések rámutattak, hogy a formázott nyerstégla és kerámia tetốcserép tele van néhány mikrométer, vagy ennél is kisebb méretũ pórusokkal és kapillárisokkal, amelyekbôl a vízcsepp eltávolításához - felületi feszültségének leküzdéséhez - több MPa nagyságú belsố nyomás létrehozása szükséges. Ekkora belsô „gôznyomás" elôállítása csak a jelenleg elterjedtnél lényegesen magasabb szárítási hômérsékleten lehetséges! A szárítási hômérséklet növelésével - a szárítási múvelet gyorsításával - minden esetben csökkent a formázott nyerstégla és kerámia tetôcserép száradási zsugorodása; jelentôsen lecsökkentve így a zsugorodás által gerjesztett húzófeszültség nagyságát.

Kulcsszavak: szárítás, mikroszerkezet, pórusszerkezet, porozitás, hōátadás

Keywords: drying, microstructure, pore-structure, porosity, heat transfer

\section{Introduction}

Engineers and experts working at brick and ceramic roof tile manufacturing plants have been engaged in making the drying of produced green bodies more efficient already since the end of the $19^{\text {th }}$ century $[1,2]$. However, the first theoretic study - significant in respect of material science as well - was hallmarked with the name of Pukall W. [3] at the end of the twentieth years of the last century. This apparent delay of the applied theoretic researches is obvious, since the demand aiming at the theoretic and experimental analysis of material flowing, transformation and thermal processes occurring during the drying of such complicated material structures like extruded green bricks or pressed ceramic green roof-tiles, presented itself for the first time only at the middle of the $20^{\text {th }}$ century, when artificial dryers came into general use $[4,5,6,7]$.

From this era it is worth mentioning the name and work of Csiszkij A.F. [8] determining not only the shrinkage, the bending- and compressive strength of the dried profiles on the basis of regression equations, but establishing at the given temperature also the "critical drying time" pertaining to the knee presenting itself at the end of the linear drying, shrinking section, based on the Bigot curves. For the analyses - for setting the regression equations - Csiszkij altered the raw material composition, the mineral- and moisture content, the drying temperature as well as the relative moisture content of the drying air. His work is all the more significant because in the field of ceramics he was the first scientific researcher to process the obtained test results by means of mathematical-statistic methods. Later Csiszkij's results were developed further on by Schmidt H. [9] and Ratzenberger H. [10 and 11] applying the quadratic polynominal regression model.
László A. Gömze

is head of Department of Ceramics and Silicate Engineering in the University of Miskolc since 1999. He has got scientific degree „Candidate of Technical and Engineering Sciences" at Moscow University M. I. S. I. in 1985, and has a wide range of experiments both in engineering and research works at different companies and in teaching of students at universities. Finishing the Civil Engineering University of Moscow

(Russia) in 1973, L. A. Gömze started his working activity as structural engineering at the design department in Hungarian firm Building Ceramics (Épületkerámia) in Budapest. In 1986 he was already the managing director of the famous Hungarian porcelain manufactory HOLLOHÁZA. Leaving Hollóháza in 1990 he used to work as associated professor at University of Miskolc. Since 1995. L. A. Gömze is regularly invited to the TU Bergakademie Freiberg, TU Madrid and other universities of EU countries. As invited professor he has reading courses for master and PhD students in topics of ceramics with extremal mechanical and physical properties, and in themes of forming, drying and syntering of ceramics and CMC materials and bodies. He also has wide range experiments in study of rheology, as well as in mechanical and mathematical modelling of rheological properties of non-linear viscoelastic-plastic materials like clay-minerals, structural ceramics and ceramic-fibre reinforced ceramic-matrix composites. He has good experiments in examination and development of new material compositions and technology both for tradition and high-tech ceramics and CMC-s. His research works are presented in 78 research reports, 3 books, 2 patents and more then 100 scientific articles. László A. Gömze is member of several Hungarian and international organization in fields of ceramics, material sciences and chemistry. He is member of „Kerpely Antal Doctoral School" of material sciences and technologies. Since 1996 he has successfully supervised several PhD students in fields of ceramics and ceramic matrix composites.

Ludmila N. Gömze is the managing director of engineering service firm IGREX Ltd. Finishing the Civil Engineering University of Moscow (Russia) in 1974 she started her working activity as structural engineer at Hungarian design institution VIZITERV in Budapest. Further she continued her job as designer engineer at firm KEVITERV in city Miskolc. In her working experiments she has met first time with the problems of productions and technologies of ceramic items at the porcelain manufactory HOLLÓHÁZA in 1987. Since then she has a wide range experiments in examination, research and development of new material compositions and technologies both of traditional and high-tech

structural ceramics as well as of ceramic matrix composites. The research works of Ludmilla $\mathrm{N}$. Gömze are presented in several research reports, conference publications and 5 scientific articles in different German and Hungarian journals.

From among the European researchers analysing the drying sensitivity and drying properties of the raw materials for brick and ceramic roof-tile production, Bálint Pál and Tóth Kálmán [12] were among the first to succeed in stating the relation between mineral composition of the mining materials used for green production and the parameters of the applied manufacturing and drying technology using the regression equation with 0,9 correlation coefficient. Their work was focused among others on plasticity, the drying sensitivity and the porosity of the dried product (profiles) as a function of the montmorillonite and chlorite content of the different mining materials used for the production and the mass ratio of grains less than $10 \mu \mathrm{m}$ resp. $2 \mu \mathrm{m}$ fractions. More publications were issued on the statistic method applied by them and the results of their research work $[13,14]$. 
Several reports were published in the journal „Építőanyag” (Building material) on the results attained in the analysis of the drying properties of mining materials for the brick and tile industry. Surely, the most important works of them are those elaborated by Bálint P. [14], Sopronyi G. [15], as well as Vértesffy K. and Verdes S. [16], testing by up-to-date mathematical and statistic methods the drying properties of the newly formed green products of the brick and tile industry as a function of the mineral content of the mining materials - the quantity of materials belonging to the caolonite, illite and smectite group. The obtained regression equations enabled the conclusion that it was the quantity - the proportion - of the mineral materials belonging to the smectite group that exercised the greatest influence on both the drying process and the physical and mechanical properties of the dry semiproducts.

\section{Materials, theoretical and experimental procedures}

Nowadays, apart from the quality, it is the specific energy costs that essentially determine the market competitiveness of a product or technology. As far as the reduction of the specific energy costs is concerned, it is of vital importance to understand and correctly interpret the thermomechanical processes occurring during drying and dehydration of brick and tile basic materials and formed green bodies [17]. The discovery and comprehension of physical-chemical connections and relations between the microstructure as well as the drying and dehydration properties of brick and tile basic materials resp. green bodies can significantly contribute to the improvement of the efficiency of the applied drying technologies and the reduction of the specific energy costs of the drying procedures [18]. At the same time the ever increasing transmission capacity of the raw material preparation and extrusion machines of the production lines applied in the brick and tile industry [19] also requires that the pressed green products be dried during a considerably shorter period. During our research work aiming at the discovery and comprehension of the relations between the material structure of the brick and ceramic roof-tile green products as well as their drying and dehydration properties, 18 basic materials - mining materials - from Hungary, 6 ones from Romania and 4 ones from Austria were analysed. Our tests were aimed at replying the following questions:

- What does the extent of drying shrinkage and drying sensitivity depend on?

- Mechanical stresses of what character and what size do occur during the drying of green bricks and roof-tiles?

- How is the drying procedure influenced by the temperature, the relative moisture content of the drying air as well as the mineral composition, the moisture content and the microstructure of the green brick?

- What can cause dehydration cracks following perfect drying?

When examining the drying properties of the green brick and pressed ceramic roof-tile, we determined first of all the mineral composition of the obtained mining materials using a Bruker D8 ADVANCE type X-ray apparatus, then established the BET and Langmuire specific surface area of the uncrushed samples taken from them by means of a Tristar-3000 apparatus. Thereafter we measured the moisture content of the obtained basic - mining - materials; and carried out the usual thermoanalytical tests by plotting the DTA, TG and DTG curves in the temperature range of

$$
20{ }^{\circ} \mathrm{C} \leq \mathrm{T} \leq 1000^{\circ} \mathrm{C}
$$

using a derivatograph. Having completed the above basic tests we prepared mixtures according to the formulas specified in the experimental plan then adjusted the moisture content values as required for forming. We used a laboratory muller to produce the grain size and grain structure required for forming, then prior to the extrusion we determined again the BET and Langmuire specific surface areas. The green profiles required for the tests were produced by means of a KEMA -PVP5 type vacuum extrusion machine, while a "HÖKER” type climatic chamber was used for drying. This type of climatic chamber has an advantage whereby the temperature and the quantity of the drying air can be regulated together with its relative moisture content and flow rate. For plotting the Bourry-Morozov drying diagrams shown in Fig. 1., we measured the length, the cross section and the mass of the tested profiles per given time units.
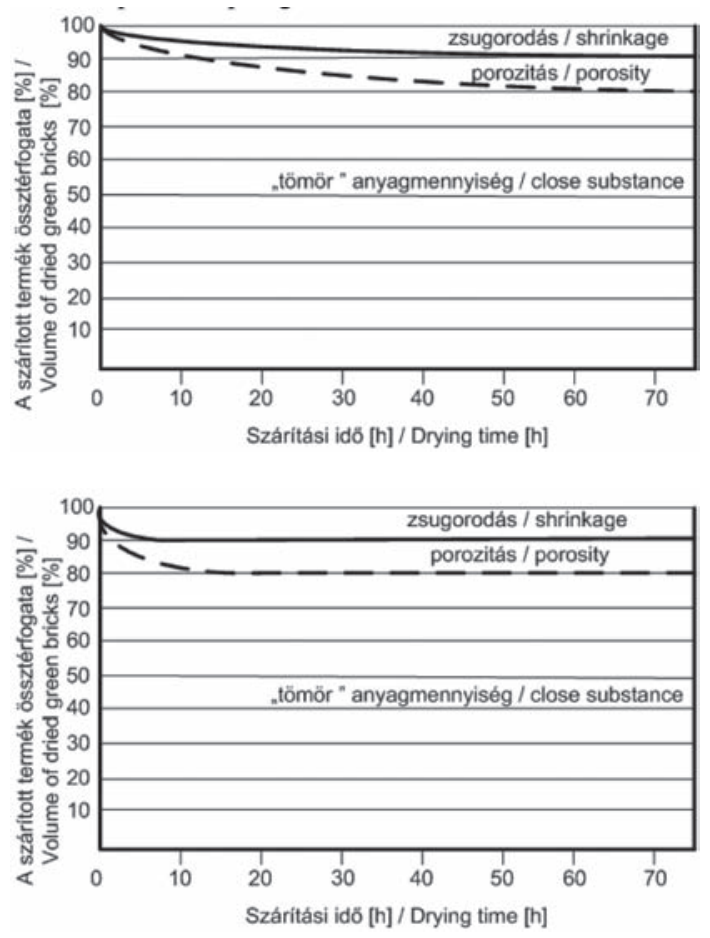

Fig. 1. Typical Bourry-Morozow diagrams of the drying procedure of the green bricks 1. ábra Nyers tégla száradási folyamatának tipikus Bourry-Morozov féle diagramja

Our tests showed that the basic materials - materials -, the Bourry-Morozow diagrams of which had a greater - more inclined - negative angular coefficient at the initial section, were more sensitive. The green bricks prepared therefrom shrank significantly quicker - more intensively - in the initial phase of the drying procedure compared to those having a less inclined negative angular coefficient in the same phase. 
For the mathematical determination - calculation - of the energy required for the convective drying of the green bricks and green ceramic roof tiles in an in-line chamber type quickdrier, a so-called agitator vessel model was used under adiabatic thermal- and energy-transfer conditions. Later, having learned the work of Junge K., Tretau A. and Specht E. [20], we used for our tests the mathematical relations developed by them. For the simulation of the kinetics of quick drying, the above authors have developed a very well applicable software as well, enabling the simple and quick modelling - testing - of the relation among the supply air mass flow, the green product water load, the energy requirement of drying, the evaporation rate and the planned drying curve.

To our regret, the Junge-Tretau-Specht software was not available for us; thus we tested the mathematical relations given in their work [20] by means of the MathCAD program wellknown for us. Mainly the curves shown in Fig. 2., taken over from the author's work, raised our interest, whereby the increase of the temperature of the drying air involves considerable decrease of the energy requirement of drying.

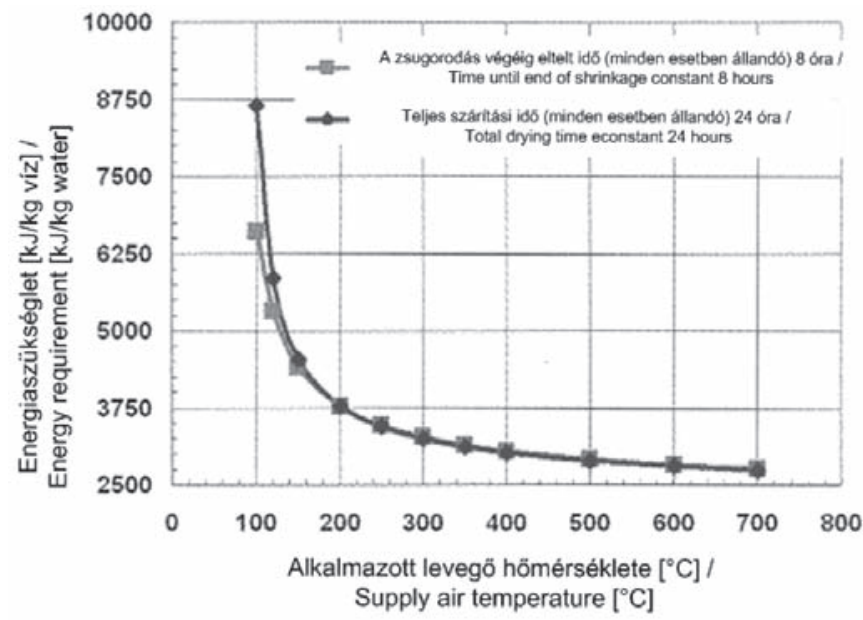

Fig. 2. Energy requirement of drying as function of supply air temperature (taken from [20])

2. ábra A szárítási energia igénye a betáplált levegö hömérsékletének függvényében (átvéve: [20])

In their above mentioned work [20] the authors also describe that as a result of quicker drying at higher temperature the drying shrinkage of the green brick products will decrease. We often experience the phenomenon of reduced drying shrinkage as well; Fig. 3 shows an example demonstrating the drying shrinkage of green bricks composed of 4 mixtures of different composition.

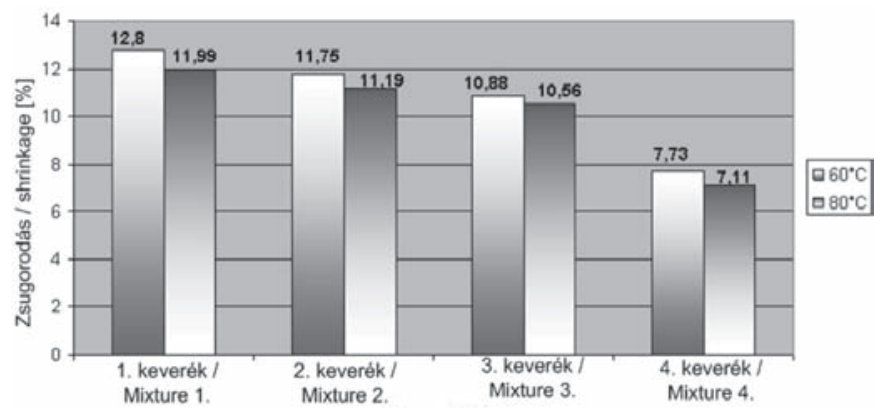

Components [dkg]

Mixture 1. Mixture 2. Mixture 3. Mixture 4.

\begin{tabular}{lrrrr} 
T & 40 & 40 & 40 & 40 \\
\hline A & 100 & 100 & 120 & 100 \\
\hline B & 100 & 100 & 100 & 100 \\
\hline D & 100 & 100 & 100 & 100 \\
\hline Sawdust & 50 & 0 & 40 & 50 \\
\hline Total & 0 & 0 & 0 & 23,4 \\
\hline
\end{tabular}

Fig. 3. Drying shrinkage of green bricks composed of 4 different composition

3. ábra Különbözö összetételü keverékböl készített nyerstéglák száradási zsugorodása

\section{Results and discussion}

Fig. 3. showing the drying shrinkage of the green bricks as a function of the mineral composition and the drying temperature, clearly demonstrates that the composition has at least the same influence on the drying shrinkage as the temperature. From among the mining materials illustrated in the figure "A" contained more of montmorillonite and illite, „B” of illite and smectite, „C" of illite and chlorite and "D" of chlorite and mainly silica flour (exceeding 50\%). At the same time materials "A" and "D” contained also muscovite and kaolinite in appr. 5 to 10 mass\%. The saw-dust added in 3 mass $\%$ as a pore-forming additive has a remarkable drying shrinkage reduction effect!

The differences in the drying shrinkage and drying sensitivity of the green bricks made of different basic materials, mixtures, revealed the importance of the mineral composition, the moisture content, the microstructure, the grain- and pore-sizes of the applied basic materials. While testing the material structures to discover the effect of the microstructure on the drying shrinkage, it was interesting to observe how the tetartoid [18] crystal structure of the quartz (Fig. 4) reminded of the water molecule structure [17]; respectively how the dipolar $\mathrm{H}-\mathrm{O}-\mathrm{H}$ chain [21] formed by the water molecules resembled the -Si$\mathrm{O}-\mathrm{Si}-\mathrm{O}$ - crystal chain of the silicate soda glass [22].

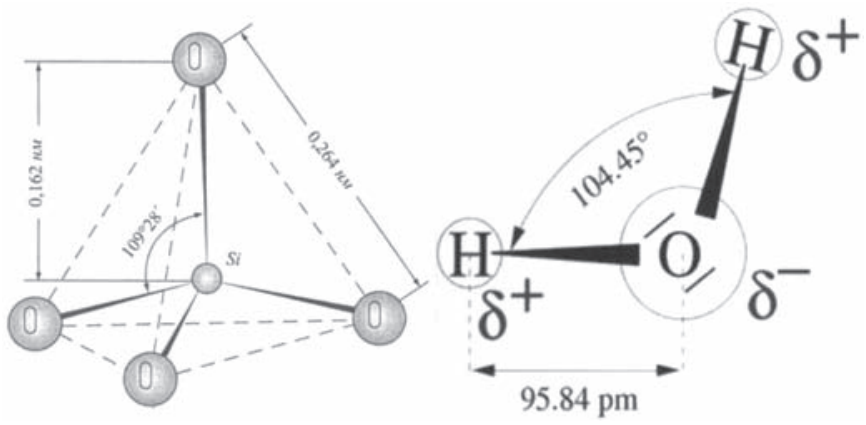

Fig. 4. Structure of the quartz crystal and the water molecule 4. ábra A kvarckristály és a vízmolekula szerkezeti felépitése

It is due partly to its above mentioned material structure, partly to its dipolar property, that water can be so properly used for wetting the basic materials of bricks and ceramic tiles, the mineral mixtures rich in quartz. At the same time it is wellknown that the tensile stress produced by the surface stress in the water drop can be determined on the basis of the following relation: 


$$
p=\frac{2 \sigma \cdot \cos \alpha}{r}, \quad[\mathrm{~Pa}]
$$

where:

$\alpha$ - wetting angle,

$\sigma$ - surface stress of the water drop, $[\mathrm{N} / \mathrm{m}]$,

$\mathrm{r}$ - radius of the water drop, $[\mathrm{m}]$.

Consequently it is essentially important to learn the microstructure (Fig. 5.) of the raw materials to be applied even before forming (extrusion).
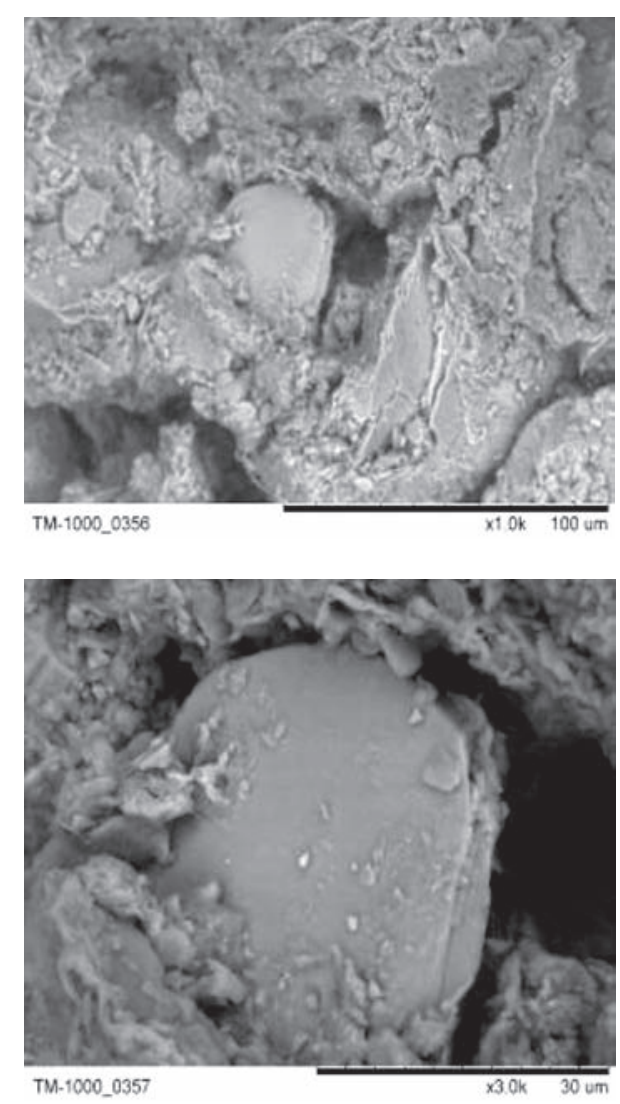

Fig. 5. Microstructure of the clay from Mezöberény

5. ábra A mezöberényi agyag mikroszerkezete

In Fig. 5. the size, the shape and the open porosity of the different grains of the mining material used for brick production can be observed well, and the form and size of the gaps (cavities) among the grains can also be seen well. By means of the figure the total volume of the pores and "gaps" in the clay used for green production can be determined as follows:

$$
V_{p \ddot{o}, a}=\sum_{i=1}^{A} V_{n p i}+\sum_{j=1}^{F} V_{z p j}+\sum_{k=1}^{C} V_{k p k}+\sum_{l=1}^{D} V_{h t l} ; \quad\left[\mathrm{m}^{3}\right]
$$

After the extrusion the free gaps among the grains will cease; part of them will be converted into closed or open pores and capillaries, while the other part of them will definitively cease; the total pore volume can be determined as follows:

$$
V_{p \ddot{o}, e}=\sum_{i=1}^{E} V_{n p i}+\sum_{j=1}^{F} V_{z p_{j}}+\sum_{k=1}^{G} V_{k p_{k}} ; \quad\left[\mathrm{m}^{3}\right]
$$

The symbols used in relations (3) and (4) are as follows:

A, B, C, E, F and G - number of the open and closed pores as well as capillaries in the clay used for green production respectively in the extruded green brick.

$\mathrm{D}$ - number of the gaps among the grains of the clay prior to extrusion.

$\mathrm{V}_{\text {npi }}$ - i-th open pore volume, $\left[\mathrm{m}^{3}\right]$,

$\mathrm{V}_{\mathrm{zpj}}$ - j-th closed pore volume, $\left[\mathrm{m}^{3}\right]$,

$\mathrm{V}_{\mathrm{kpL}}-\mathrm{k}$-th capillary volume, $\left[\mathrm{m}^{3}\right]$,

$\mathrm{V}_{\mathrm{htl}}$ - l-th gap volume among the grains, $\left[\mathrm{m}^{3}\right]$.

The specific pore volume of the clay used for green production can be determined by means of the following relation:

$$
V_{a f}=\frac{V_{a \ddot{o}}}{V_{p \ddot{o}, a}} \cdot 100 \% ; \quad[\%
$$

while for the determination of the specific pore volume of the extruded green brick the following relation can be applied:

$$
V_{t f}=\frac{V_{n t \ddot{o}}}{V_{p \ddot{o}, e}} \cdot 100 \%,
$$

where:

$\mathrm{V}_{\mathrm{a}, \mathrm{o}}$ - total volume of the clay used for green production, before extrusion; $\left[\mathrm{m}^{3}\right]$

$\mathrm{V}_{\mathrm{nt}, \mathrm{o}}$ - total volume of the extruded green „compact” brick, before drying; $\left[\mathrm{m}^{3}\right]$

While the green products for brick production are extruded, respectively the green ceramic tiles are pressed, the water used for the forming processes "gets jammed" into these open and closed pores, the capillaries and gaps among the grains, which is to be removed during drying. The smaller the pores filled with water are - in case of identical total volume - the more energy will be required for their removal (evaporation). Thus for example in case of a $200 \mu \mathrm{m}$ diameter pore the heat transferred to the water drop shall ensure that the pressure produced by evaporation surpass the 1,5 MPa tensile stress produced by the surface stress of the water drop. In case of a water drop jammed in a $2 \mu \mathrm{m}$ diameter pore this value is already $150 \mathrm{MPa}$ ! Driers and drying technologies applied at present are not capable of producing evaporation „steam-pressure” of such an extent. Among others it is due to the high pressure required to remove the water from the micropores that at least 1 to $3 \%$ water still remains in each case in the green brick and ceramic roof-tile products when drying is over.

Quick drying at high temperature of porous materials like green bricks or ceramic roof-tiles raises several questions. For example: What will happen when the water in steam form passes across the „wall” of the product at high pressure, through a nanometre diameter, needle-like capillary and arrives in one or more macrometer size pores [23]? or: How can the phenomenon of the so-called "heat pipe effect" observable in such cases be explained [17]? The reply to these questions can be found only in the changes occurred in the material structure - the micro- and nano-structure - of the formed green brick and ceramic roof-tile during the drying procedure (Fig. 6 and 7). 

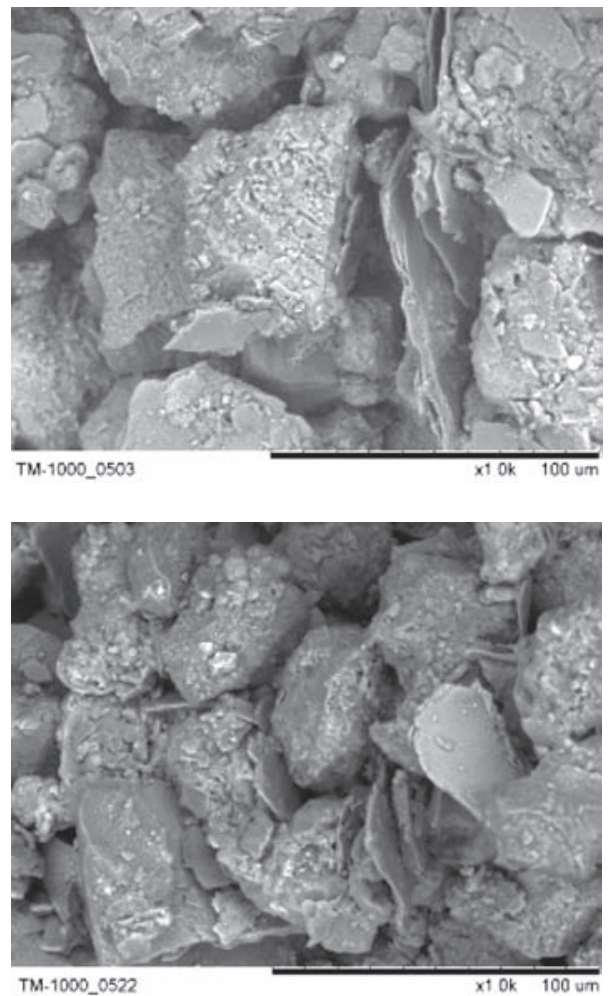

Fig. 6. Change in the material structure of the green brick in case of drying at $150^{\circ} \mathrm{C}$ and $300^{\circ} \mathrm{C}$

6. ábra A nyers tégla anyagszerkezetben végbement változás $150^{\circ} \mathrm{C}$ és $300^{\circ} \mathrm{C}$-os száritás esetén

Fig. 6. illustrating the material structure at thousand times magnification demonstrates how the surface of the grains building up the green brick, the form and size of the gaps among the grains change during the drying procedure as a result of temperature increase. When the drying temperature is increased from $150^{\circ} \mathrm{C}$ to $300^{\circ} \mathrm{C}$, the size of the gaps among the grains considerably increases, while the grains themselves will become smaller due to the thermal shrinkage. The gaps among the grains will continue to exist in the form of closed pores or capillaries even after burning, thus the applied drying temperature and technology are of decisive importance in respect of the material structure, the thermal physical properties and the mechanical strength of the burnt brick and tile products.

Fig. 7. demonstrates the material structural changes over the surface of a single grain of the green brick as a function of the drying temperature, at ten thousand times magnification.

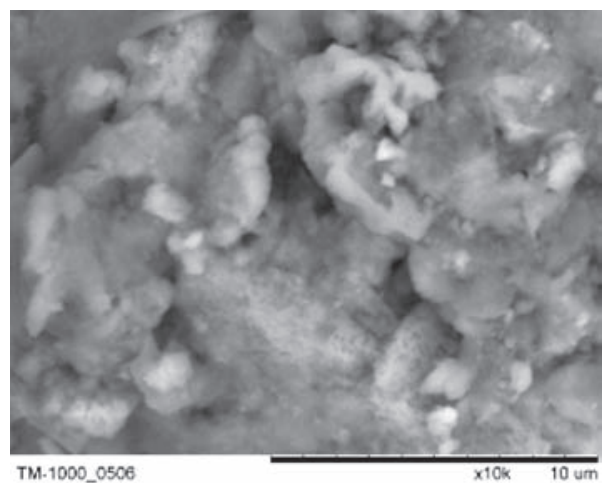

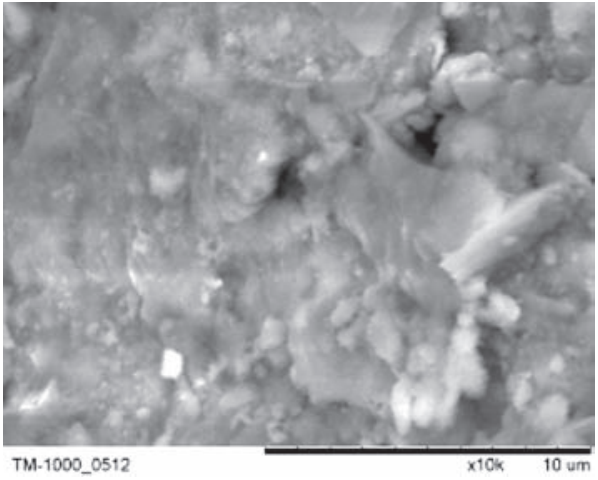

Fig. 7. Change of the material structure of a single grain

7. ábra A szemcse anyagszerkezetének változása a száritó hőmérséklet hatására

According to Fig. 7, as the temperature is increased from $150{ }^{\circ} \mathrm{C}$ to $300^{\circ} \mathrm{C}$, the tested independent grain - of some $10 \mu \mathrm{m}$ size only - became essentially more compact; while the number of the open pores over its surface considerably decreased and their size became smaller. Simultaneously, as the drying temperature increased the surface of the tested grain became less articulated, while the number of the submicronous and nano-size crystals - grains - considerably increased.

\section{Conclusions}

The results of the performed thermodynamical analyses, drying experiments and material structural tests can be summarised as follows:

- Prior to drying, the material structure of the formed green brick and ceramic roof-tile is rather articulated, it is full of some micrometer or smaller pores and capillaries, thus internal pressure of more MPa shall be produced to surpass the surface stress. The production of such an internal „steam-pressure" requires considerably higher drying temperature compared to the value being generally in use at present!

- As the drying temperature was increased - the drying process was accelerated - the drying shrinkage of the formed green bricks and ceramic roof-tiles decreased in each case, reducing thereby the tensile stress in the drying product produced by the shrinkage.

- The material structural tests performed on the produced profiles before and after drying revealed that as the drying temperature increased, the gap among the micrograins increased as well, while the grains themselves shrunk. At the same time due to the great number of gaps - pores and capillaries - among the micrograins, and their increased size resulted from more intensive drying, the shrinkage of the produced profiles decreased as far as the macro-size was concerned.

- The drying temperature and the drying dynamics can essentially influence the material structure of the brick and ceramic roof-tile, whereby also their mechanical and physical properties, most important in respect of their application, will be influenced. The discovery and comprehension of these relations require further tests and researches. 


\section{References}

[1] Nohratyan K. A.: Sushka i obzhig v promishlennosti stroitel'noi keramiki; Kiev; Naukova Dumka (1962)

[2] Tamás Ferenc: Szilikátipari kézikönyv (Handbook of Silicate Industy); Müszaki Könyvkiadó, Budapest (1982)

[3] Pukall W.: Über die Vorgange beim Trocknen Keramicher Rohmassen; Sprechsaal; No. 22., p. 429-450 (1928)

[4] Macay H.H: Clay-material relationships and the international mechanism of drying; Trans Brit. German Soc.; v. 41. (1942)

[5] Nossova S. A.: Sushilki dlya glin; Ministerstvo Promislenosti Stroitel'nih materialov; Moscow (1946)

[6] Bulavin I. A.: Proizvodstvo keramicheskih plitok; Promstrojizdat, Moscow, (1949)

[7] Budnikov P. P: Technologie der keramischer Erzeugnisse; VEB Verlag Technik; Berlin (1953)

[8] Csiskij A. F.: Steklo i keramika, v. 4; p: 11-13 (1954)

[9] Schmidt H.: Physikalische und chemische Untersuchungsverfahren in der Grobkeramik, Teil VIII., Sprechsaal 113;p. 125-127. (1980)

[10] Ratzenberger H.: Bestimung der Trocknungsempfindlichkeit toniger Materialen; Unveröffentlichter Forschungsbericht; IBK; Weimar (1989)

[11] Ratzenberger H.: Bestimung der Trocknungsempfindlichkeit nach neuen Gesichtspunkten, Baustoffindustrie No. 2. p.: 48-49. (1990)

[12] Bálint P., Tóth K.: Analyse einer Vielzahl von Ziegelton-Kenndaten durch Datenverarbeitung mittels Computer; Tonindustrie Ztg. V. 97., No., 5. p.: 122-125 (1973)

[13] Bálint P., Szőke B., Juhász J., Skorecz T.: Equilibrium moisture diagrams for the drying of clays; Ceramics International, v. 7., No. 1., p. 35-39 (1981)
[14] Tóth K., Bálint P., Bakos J: The Examination of Drying Sensitivity of Hungarian Ceramic Raw Materials by Alviset's Method; Építőanyag, v. 20. No.8., p.302-306. (1968)

[15] Sopronyi Gábor: Testing of Drying Sensitivity be the „Barelattograph”; Építőanyag, v. 30. No.6., p.219-222. (1978)

[16] Vértesffy K., Verdes S.: Connexion between Drying and Physical Chemical Characteristics of Ceramic Raw Materials and Bodies; Építöanyag, v. 37. No.7., p.193-201. (1985)

[17] Junge K., Tretan A., Specht E: Drying of green bricks - Material-related principles, kinetics and energetics; Zi-ANNUAL 2008. p. 28-71. Edited by Fischer A., Bauverlag BV GmbH, Gütersloh (2008)

[18] Rabuhin A. I., Saveliev V. G.: Fizitseskya himiya tugoplavkih nemetallitseskih i silikatnih soedinenij; Infra-M; Moscow (2004)

[19] Händle F. at all: Extrusion in Ceramics; Springer Verlag, Berlin-Heidelberg (2007)

[20] Junge K., Tretan A., Specht E.: Energy expenditure for drying of green bricks in chamber dryers; Zi-ANNUAL 2007., p. 25-38; by Müller W. and Fisher A.; Bauverlag BV GmbH; Gütersloh (2007)

[21] Emilian G. P., Corbara F.: Technologia ceramica le materie prime; volume 1., ISBN: 88-8138-043-9 (2001)

[22] Gömze A. L.: Kerámiatan - jegyzet; Anyagmérnöki BSc (nappali); http:// keramia.uni-miskolc.hu

[23] Schlünder E-U: Drying of Porous Material During the Constant and the Falling Rate Period; A Critical Review of Existing Hypotheses; Drying Technology; v. 22., No. 6. p: 1517-1532 (2004) 